\title{
Irrigation Management through Wastewater Recycling on Different Growth Indices of Cotton
}

\author{
N. Jagathjothi" and M. Mohamed Amanullah \\ Department of Agronomy, Tamil Nadu Agricultural University, Coimbatore - 3, \\ Tamil Nadu, India \\ *Corresponding author
}

\begin{abstract}
A B S T R A C T
Keywords

Wastewater,

Effluent, Recycling,

Growth indices,

Amendments

Article Info

Accepted:

10 August 2018

Available Online:

10 September 2018

A field experiment was conducted at the Common Effluent Treatment Plant (CETP), Dindigul, Tamil Nadu during kharif season to study the irrigation management through wastewater recycling on growth parameters of cotton. Field experiment was laid out in factorial randomized block design with four replications. The results shown that the mixing proportion of $25 \%$ treated tannery effluent (TTE) $+75 \%$ domestic wastewater (DWW) recorded higher plant height, root length, dry matter production, leaf area index, leaf area ratio, absolute growth rate, crop growth rate and relative growth rate when compared to other mixing proportions. But all the growth indices were lesser with $100 \%$ TTE application. With regard to amendments, application of gypsum recorded enhanced response than VAM and control. Among the mixing proportion of irrigation source and amendments, application of $25 \% \mathrm{TTE}+75 \%$ DWW with gypsum registered higher growth indices in cotton compared to normal water irrigation with gypsum.
\end{abstract}

\section{Introduction}

Leather industries of India contribute $15 \%$ of the worlds' total leather production. It provides employment opportunity to about 3 million people of economically weaker populations and thus leather industry by which occupies an important role in Indian economy. However, it also suffers from the negative consequences of environmental impact due to indiscriminate disposal of its waste (Soyalsan and Karaguzel, 2007). Especially it generates and discharge huge quantity of effluent every day. The discharged effluent is loaded with the higher concentration of chemical salts. Hence, extensive disposal of tannery effluent degraded the productive agriculture land and water sources. In Tamil Nadu, there are 61 tanneries situated in and around of Dindigul region. With high generation of effluent from the tannery treatment plant of this region will provide vast scope to recycling effluent as irrigation source with high availability of domestic wastewater in the city. This will give affordable result to reduce pressure on fresh water demand.

With this back drop, the present investigation was carried out to study the irrigation management through wastewater recycling on different growth indices of cotton by mixed use of treated tannery effluent and domestic 
wastewater as alternate source of irrigation water for agricultural production.

\section{Materials and Methods}

The field experiment was carried out during kharif season 2011-12 at the common effluent treatment plant (CETP), Dindigul to study the irrigation management through wastewater recycling on growth parameters of cotton. The soil type was red sandy clay loam in texture. The experimental soil was neutral with low EC, low in available nitrogen, medium in available phosphorus and high in available potash. The experiment was laid out in factorial randomized block design with four replications. Treatment comprised six levels of irrigation sources viz., $\mathrm{I}_{1}-25 \%$ treated tannery effluent (TTE) $+75 \%$ domestic wastewater (DWW), $\mathrm{I}_{2}-50 \% \mathrm{TTE}+50 \% \mathrm{DWW}, \mathrm{I}_{3}-75 \%$ TTE $+25 \%$ DWW, $\mathrm{I}_{4}-100 \%$ TTE, $\mathrm{I}_{5}-100 \%$ DWW and $\mathrm{I}_{6}$ - control (normal water) treatments under factor $\mathrm{A}$ and three amendments viz., $\mathrm{A}_{\mathrm{o}}$ - control (without amendment), $A_{1}$ - gypsum and $A_{2}-$ VAM as treatments under factor B.

The well decomposed FYM at the rate of 12.5 tonnes $\mathrm{ha}^{-1}$ was applied at the time of land preparation. Cotton was cultivated as a test crop with $90 \mathrm{x} 60 \mathrm{~cm}$ spacing. The recommended dose of 120:60:60 $\mathrm{kg}$ of NPK $\mathrm{ha}^{-1}$ was applied in the form of urea, single super phosphate and muriate of potash, respectively. Half the dose $(50 \%)$ of $\mathrm{N}$ and $\mathrm{K}$ and full dose of $\mathrm{P}$ were applied as basal dose as band placement $5 \mathrm{~cm}$ away and $5 \mathrm{~cm}$ below the seed row. The remaining $50 \%$ of $\mathrm{N}$ and $\mathrm{K}$ were applied in two equal splits at the time of square initiation (45 DAS) combined with earthing up and boll formation stage (65 DAS). VAM inoculum (Glomus intraradices) was applied at the rate of $100 \mathrm{~kg} \mathrm{ha}^{-1}$ and gypsum applied as basal at the rate of $4 \mathrm{t} \mathrm{ha}^{-1}$ as general recommendation. As per the treatment, equal quantity of irrigation water was given for each plot throughout the experiment period with the help of scale marked water tanks. The plant height was measured from the ground level to growing point of the plant at 120 days after sowing (DAS) and expressed in $\mathrm{cm}$. Root length was recorded at 120 DAS in each treatment and expressed in $\mathrm{cm}$. Regarding dry matter production, The whole plant samples were collected at 120 DAS and then oven dried at $80^{\circ} \mathrm{C}$ till a constant weight was obtained. The samples were weighed and expressed as total dry matter production (DMP) in $\mathrm{kg} \mathrm{ha}^{-1}$. Other growth indices was calculated by using the following formulas,

\section{Leaf Area Index (LAI)}

From randomly selected cotton plants in each treatment, leaf length and maximum width of the third leaf from the top was measured in five representative samples. Total number of leaves in each plant was counted. These observations were made at 40, 80 and 120 DAS. LAI was calculated using the following formula as suggested by Ashley et al., (1965).
LAI $=\overline{\text { Land area occcupied by plant }\left(\mathrm{cm}^{2}\right)}$

Where,

$\mathrm{L}$ - Length of the leaf $(\mathrm{cm})$

W - Width of the leaf $(\mathrm{cm})$

$\mathrm{K}$ - Constant factor $(0.775)$

$\mathrm{N}$ - Number of leaves per plant

\section{Leaf Area Ratio (LAR)}

LAR was calculated by using the formula given by Radford (1967) and expressed in $\mathrm{cm}^{2}$ $\mathrm{g}^{-1}$.

Leaf area perplant

LAR $=\overline{\text { Total plant dry weight }}$ 


\section{Absolute growth rate (AGR)}

AGR was calculated by using the formula suggested by Radford (1967) and expressed in 'g' per plant per day.

$\mathrm{AGR}=\frac{\mathrm{W}_{2}-\mathrm{W}_{1}}{\mathrm{t}_{2}-\mathrm{t}_{1}}$

Where,

$\mathrm{W}_{1}$ and $\mathrm{W}_{2}$ - Dry weight of the whole plant at time $\mathrm{t}_{1}$ and $\mathrm{t}_{2}$, respectively $(\mathrm{g})$

$\mathrm{t}_{1}$ and $\mathrm{t}_{2}-$ Time interval (days)

\section{Crop Growth Rate (CGR)}

Crop Growth Rate (CGR) is defined as the rate of increase in dry weight per unit land area per unit time. CGR was calculated from the dry weight of whole plant using the formula suggested by Watson (1958) and expressed in $\mathrm{g} \mathrm{m}^{-2} \mathrm{day}^{-1}$.

$\mathrm{CGR}=\frac{\mathrm{W}_{2}-\mathrm{W}_{1}}{\mathrm{P}\left(\mathrm{t}_{2}-\mathrm{t}_{1}\right)}$

Where,

$\mathrm{W}_{1}$ and $\mathrm{W}_{2}$ - Dry weight of the whole plant at time $\mathrm{t}_{1}$ and $\mathrm{t}_{2}$, respectively (g)

$\mathrm{t}_{1}$ and $\mathrm{t}_{2}-$ Time interval (days)

$\mathrm{P}$ - Land area occupied by the crop $\left(\mathrm{m}^{2}\right)$.

\section{Relative growth rate (RGR)}

RGR was calculated using the formula suggested by Williams (1946) and expressed in $\mathrm{mg} \mathrm{g}^{-1}$ day $^{-1}$.

$$
\mathrm{RGR}=\frac{\operatorname{Loge} \mathrm{W}_{2}-\log \mathrm{e} \mathrm{W}_{1}}{\mathrm{t}_{2}-\mathrm{t}_{1}}
$$

Where,

$\mathrm{W}_{1}$ and $\mathrm{W}_{2}$ - Dry weight of the whole plant at time $\mathrm{t}_{1}$ and $\mathrm{t}_{2}$, respectively $(\mathrm{g})$

\section{Results and Discussion}

Plant height, root length and dry matter production (Table 1)

Irrigation of normal water $\left(\mathrm{I}_{6}\right)$ recorded taller plants of $74.76 \mathrm{~cm}$ at 120 DAS. This was followed by $100 \%$ DWW. Among the mixing ratios, $25 \%$ TTE $+75 \%$ DWW recorded taller plants. The least plant height was observed under $100 \%$ TTE. With respect to amendments, application of gypsum $\left(\mathrm{A}_{1}\right)$ recorded taller plants at all the stages of observation compared to VAM and control.

Application of normal water recorded higher root length (49.45 $\mathrm{cm}$ at $120 \mathrm{DAS})$ compared to other irrigation treatments. This was followed by $100 \% \mathrm{DWW}\left(\mathrm{I}_{4}\right)$. Among the mixing ratios, $25 \%$ TTE + 75\% DWW (1:3) recorded higher root length. The least root length was noticed under $100 \%$ TTE. Regarding amendments, higher root length was observed under addition of gypsum $\left(\mathrm{A}_{1}\right)$ at 120 DAS compared to other treatments.

Irrigation of normal water recorded higher dry matter production of $2403 \mathrm{~kg} \mathrm{ha}^{-1}$ at 120 DAS. The least dry matter production was observed under $100 \%$ TTE $\left(\mathrm{I}_{4}\right)$.

With regard to amendments, gypsum $\left(\mathrm{A}_{1}\right)$ recorded higher dry matter production of 1973 $\mathrm{kg} \mathrm{ha}^{-1}$ at 120 DAS than the other treatments.

\section{Leaf area index (LAI) and Leaf area ratio (LAR) (Table 2)}

Normal water irrigation recorded higher LAI of 0.40, 2.84 and 2.11 at 40, 80 and 120 DAS. This was followed by $100 \%$ DWW. Among 
the mixing ratios, $25 \%$ TTE $+75 \%$ DWW $\left(\mathrm{I}_{1}\right)$ recorded higher LAI than other mixing ratios. Use of $100 \%$ TTE for irrigation recorded the least LAI at all the stages. Regarding amendments, application of gypsum recorded higher LAI $(0.29,2.21$ and 1.53 at 40, 80 and 120 DAS) than control and VAM $\left(\mathrm{A}_{2}\right)$.

Irrigation of normal water recorded higher LAR of $103.35,148.16$ and $63.69 \mathrm{~cm}^{2} \mathrm{~g}^{-1}$ at 40, 80 and 120 DAS, respectively. The least LAR was recorded under $100 \%$ TTE.

With respect to amendments, addition of gypsum registered higher LAR of 79.12, 136.81 and $58.29 \mathrm{~cm}^{2} \mathrm{~g}^{-1}$ at 40,80 and 120 DAS, respectively which was followed by $\operatorname{VAM}\left(\mathrm{A}_{2}\right)$.

Absolute growth rate (AGR), crop growth rate (CGR) and relative growth rate (RGR) (Table 3)

AGR was higher under normal water which was followed by $100 \%$ DWW. Among the mixing proportions, $25 \% \mathrm{TTE}+75 \% \mathrm{DWW}$ recorded higher AGR. Irrigation of $100 \%$ TTE the registered least RGR compared to other treatments. Gypsum application recorded higher AGR of 0.76 and $0.63 \mathrm{~g} \mathrm{day}^{-1}$ at $40-80$ and 80-120 DAS, respectively than the other treatments.

Irrigation of normal water recorded higher CGR of 3.79 and $3.30 \mathrm{~g} \mathrm{~m}^{-2}$ day $^{-1}$ between $40-$ 80 and 80-120 DAS, respectively. This was followed by $100 \%$ DWW. The least CGR (2.03 and $1.44 \mathrm{~g} \mathrm{~m}^{-2}$ day $^{-1}$ at 40-80 and 80-120 DAS) was registered under $100 \%$ TTE. With respect to amendments, gypsum recorded higher CGR compared to control and VAM application.

Normal water irrigation showed higher RGR of 35.92 and $12.70 \mathrm{mg} \mathrm{g}^{-1}$ day $^{-1}$ between $40-80$ and 80-120 DAS, respectively. This was followed by $100 \%$ DWW and $25 \%$ TTE + $75 \%$ DWW. The least RGR was registered under $100 \%$ TTE. Regarding the amendments, higher RGR was recorded under gypsum application followed by VAM application.

\section{Plant height}

The taller plants were observed under normal water followed by $100 \%$ DWW due to better utilization of nutrients (Jagathjothi et al., 2011). The least plant height was recorded under $100 \%$ TTE (Table 1). The plant height increased with increased dilution of tannery effluent and higher dilution of 1:3 ratio of TTE and DWW registered taller plants among the other mixing ratios. Presence of salts in the effluent led to increased osmotic pressure and affected plant growth. This was in conformity with the earlier findings of Tayyar and Yapici (2007) in bread wheat.

Application gypsum recorded taller plants compared to VAM and control. This might be due to improved soil chemical properties because of addition of gypsum.

\section{Root length}

Regarding root length, application of normal water recorded higher root length and among the mixing proportions, $25 \%$ TTE $+75 \%$ DWW irrigation recorded increased root length (Table 1). The root length gradually decreased with successive increase in concentration of treated tannery effluent level. This is also in conformity with the earlier findings of Indra (2003).

Among the amendments, gypsum application recorded higher root length compared to other treatments. Improved soil structure by gypsum application might have helped for the better development of root. This result is line with the findings of Ritchey et al., (1995) in cereal crops. 
Table.1 Influence of wastewater irrigation management on plant height, root length and DMP of cotton at 120 days after sowing

\begin{tabular}{|c|c|c|c|}
\hline Treatment & $\begin{array}{c}\text { Plant height } \\
(\mathrm{cm})\end{array}$ & $\begin{array}{l}\text { Root length } \\
(\mathrm{cm})\end{array}$ & $\begin{array}{c}\text { DMP at harvest } \\
\left(\mathrm{kg} \mathrm{ha}^{-1}\right)\end{array}$ \\
\hline \multicolumn{4}{|l|}{ Irrigation water } \\
\hline $\mathrm{I}_{1}: 25 \% \mathrm{TTE}+\mathbf{7 5 \%} \mathrm{DWW}$ & 69.02 & 44.38 & 1927 \\
\hline $\mathbf{I}_{2}: 50 \% \mathrm{TTE}+\mathbf{5 0} \% \mathrm{DWW}$ & 63.89 & 40.90 & 1683 \\
\hline $\mathrm{I}_{3}: 75 \% \mathrm{TTE}+25 \% \mathrm{DWW}$ & 60.39 & 37.05 & 1508 \\
\hline $\mathrm{I}_{4}: 100 \% \mathrm{TTE}$ & 58.13 & 33.80 & 1371 \\
\hline$I_{5}: 100 \% \mathrm{DWW}$ & 72.20 & 46.33 & 2019 \\
\hline$I_{6}:$ Control (Normal Water) & 74.76 & 49.45 & 2403 \\
\hline SEd & 2.66 & 2.15 & 124 \\
\hline $\mathrm{CD}(P=0.05)$ & 5.67 & 4.59 & 264 \\
\hline \multicolumn{4}{|l|}{ Amendments } \\
\hline $\mathbf{A}_{0}:$ Control & 61.9 & 39.12 & 1693 \\
\hline $\mathbf{A}_{1}:$ Gypsum & 71.1 & 44.64 & 1973 \\
\hline $\mathbf{A}_{2}: \mathbf{V A M}$ & 66.2 & 42.20 & 1789 \\
\hline SEd & 1.88 & 1.52 & 88 \\
\hline $\mathrm{CD}(P=0.05)$ & 4.00 & 3.24 & 187 \\
\hline
\end{tabular}

(TTE: Treated Tannery Effluent, DWW: Domestic Waste Water)

Table.2 Influence of wastewater irrigation management on leaf area index (LAI) and leaf area ratio $\left(\mathrm{cm}^{2} \mathrm{~g}^{-1}\right)$ of cotton

\begin{tabular}{|c|c|c|c|c|c|c|}
\hline \multirow[t]{2}{*}{ Treatment } & \multicolumn{3}{|c|}{ Leaf Area Index (LAI) } & \multicolumn{3}{|c|}{ leaf area ratio $\left(\mathrm{cm}^{2} \mathrm{~g}^{-1}\right)$} \\
\hline & 40 DAS & 80 DAS & 120 DAS & 40 DAS & 80 DAS & $120 \mathrm{DAS}$ \\
\hline \multicolumn{7}{|l|}{ Irrigation water } \\
\hline $\mathrm{I}_{1}: 25 \% \mathrm{TTE}+\mathbf{7 5} \% \mathrm{DWW}$ & 0.28 & 1.99 & 1.50 & 79.20 & 130.20 & 60.86 \\
\hline $\mathrm{I}_{2}: 50 \% \mathrm{TTE}+\mathbf{5 0 \%} \mathrm{DWW}$ & 0.21 & 1.78 & 1.25 & 58.15 & 127.49 & 52.26 \\
\hline $\mathrm{I}_{3}: 75 \% \mathrm{TTE}+25 \% \mathrm{DWW}$ & 0.18 & 1.64 & 1.09 & 50.44 & 123.63 & 44.15 \\
\hline $\mathrm{I}_{4}: 100 \% \mathrm{TTE}$ & 0.15 & 1.37 & 0.87 & 46.29 & 118.37 & 40.17 \\
\hline$I_{5}: 100 \%$ DWW & 0.36 & 2.28 & 1.73 & 92.23 & 136.90 & 62.78 \\
\hline$I_{6}:$ Control (Normal Water) & 0.40 & 2.84 & 2.11 & 103.35 & 148.16 & 63.69 \\
\hline SEd & 0.03 & 0.18 & 0.10 & 4.27 & 6.37 & 2.60 \\
\hline $\mathrm{CD}(P=0.05)$ & 0.07 & 0.39 & 0.22 & 9.10 & 13.58 & 5.53 \\
\hline \multicolumn{7}{|l|}{ Amendments } \\
\hline $\mathbf{A}_{0}:$ Control & 0.21 & 1.79 & 1.34 & 58.71 & 123.82 & 47.13 \\
\hline $\mathbf{A}_{1}:$ Gypsum & 0.29 & 2.21 & 1.53 & 79.12 & 136.81 & 58.29 \\
\hline $\mathbf{A}_{2}:$ VAM & 0.29 & 1.94 & 1.40 & 77.00 & 131.74 & 56.53 \\
\hline SEd & 0.02 & 0.13 & 0.07 & 3.02 & 4.51 & 1.84 \\
\hline $\mathrm{CD}(P=0.05)$ & 0.05 & 0.27 & 0.16 & 6.43 & 9.61 & 3.91 \\
\hline
\end{tabular}

(TTE: Treated Tannery Effluent, DWW: Domestic Waste Water, DAS: Days After Sowing) 
Table.3 Influence of wastewater irrigation management on absolute growth rate, crop growth rate and relative growth rate of cotton

\begin{tabular}{|c|c|c|c|c|c|c|}
\hline \multirow[t]{2}{*}{ Treatment } & \multicolumn{2}{|c|}{$\begin{array}{l}\text { Absolute Growth } \\
\text { Rate }\left(\mathrm{g} \mathrm{day}^{-1}\right)\end{array}$} & \multicolumn{2}{|c|}{$\begin{array}{l}\text { Crop Growth Rate } \\
\left(\mathrm{g} \mathrm{m}^{-2} \text { day }^{-1}\right)\end{array}$} & \multicolumn{2}{|c|}{$\begin{array}{l}\text { Relative Growth Rate } \\
\left(\mathrm{mg} \mathrm{g}^{-1} \text { day }^{-1}\right)\end{array}$} \\
\hline & $\begin{array}{l}40-80 \\
\text { DAS }\end{array}$ & $\begin{array}{c}\text { 80-120 } \\
\text { DAS }\end{array}$ & $\begin{array}{l}40-80 \\
\text { DAS }\end{array}$ & $\begin{array}{l}\text { 80-120 } \\
\text { DAS }\end{array}$ & $\begin{array}{l}40-80 \\
\text { DAS }\end{array}$ & $\begin{array}{l}\text { 80-120 } \\
\text { DAS }\end{array}$ \\
\hline \multicolumn{7}{|l|}{ Irrigation water } \\
\hline $\mathrm{I}_{1}: 25 \% \mathrm{TTE}+\mathbf{7 5} \% \mathrm{DWW}$ & 0.71 & 0.59 & 2.84 & 2.35 & 34.21 & 12.00 \\
\hline $\mathrm{I}_{2}: 50 \% \mathrm{TTE}+\mathbf{5 0 \%} \mathrm{DWW}$ & 0.65 & 0.49 & 2.59 & 1.96 & 33.57 & 11.11 \\
\hline $\mathrm{I}_{3}: 75 \% \mathrm{TTE}+25 \% \mathrm{DWW}$ & 0.61 & 0.42 & 2.42 & 1.68 & 33.08 & 10.32 \\
\hline $\mathrm{I}_{4}: 100 \% \mathrm{TTE}$ & 0.51 & 0.36 & 2.03 & 1.44 & 30.30 & 10.13 \\
\hline $\mathrm{I}_{5}: 100 \% \mathrm{DWW}$ & 0.78 & 0.68 & 3.13 & 2.72 & 34.81 & 12.58 \\
\hline$I_{6}:$ Control (Normal Water) & 0.95 & 0.82 & 3.79 & 3.30 & 35.92 & 12.70 \\
\hline SEd & 0.05 & 0.03 & 0.12 & 0.10 & 1.06 & 0.55 \\
\hline $\mathrm{CD}(P=0.05)$ & 0.10 & 0.07 & 0.25 & 0.22 & 2.27 & 1.18 \\
\hline \multicolumn{7}{|l|}{ Amendments } \\
\hline $\mathbf{A}_{0}:$ Control & 0.65 & 0.51 & 2.61 & 2.04 & 32.66 & 10.95 \\
\hline $\mathbf{A}_{1}:$ Gypsum & 0.76 & 0.63 & 3.02 & 2.50 & 34.53 & 12.26 \\
\hline $\mathbf{A}_{2}: \mathbf{V A M}$ & 0.69 & 0.55 & 2.77 & 2.19 & 33.76 & 11.21 \\
\hline SEd & 0.03 & 0.02 & 0.08 & 0.07 & 0.75 & 0.39 \\
\hline $\mathrm{CD}(P=0.05)$ & 0.06 & 0.04 & 0.18 & 0.15 & 1.60 & 0.83 \\
\hline
\end{tabular}

(TTE: Treated Tannery Effluent, DWW: Domestic Waste Water, DAS: Days After Sowing)

\section{Dry matter production}

Dry matter production (DMP) was higher with application of normal water and irrigation with $25 \%$ TTE $+75 \%$ DWW recorded higher DMP among all the mixing ratios of TTE and DWW (Table 1).

The dilution of effluent with DWW might have reduced the salt concentration in the soil and increased the uptake of nutrients and the resultant better growth has led to higher DMP. Similar findings have been reported by Sharma and Mehrotra (1993) in Triticum aestivum.

Regarding amendments, gypsum registered higher DMP than VAM and controls at all the stages. Gypsum might have facilitated higher uptake of nutrients thereby production higher DMP.

\section{Leaf area index and leaf area ratio}

The LAI and LAR were higher under normal water application (Table 2). This was followed by $100 \%$ domestic wastewater. Regarding mixing proportions, $25 \% \mathrm{TTE}+75 \% \mathrm{DWW}$ (1:3) registered higher LAI and LAR due to reduced salt content in irrigation source while, irrigation with 2:2 and 3:1 mixing ratios increased the salinity of soil which reflected in reduced growth and photosynthetic activity which might be the reason for reduction of LAI and LAR. Similar trend of result was reported by Amer (2010) in corn.

Among the amendments, application of gypsum recorded higher LAI and LAR. This might be due to the better growth of the plants by higher nutrient uptake under gypsum applied treatments. 


\section{Absolute growth rate, crop growth rate and relative growth rate}

With regard to AGR, CGR and RGR, normal water recorded higher crop growth rates (Table $3)$. This was followed by $100 \%$ DWW and mixing ratio of $1: 3$ (25\% TTE $+75 \%$ DWW). The growth rates increased with reduction in the concentration of TTE by diluting with DWW. This might be due to reduced accumulation of salts in the soil as well as in plant parts.

Application of gypsum recorded higher crop growth rates compared to other treatments. The least growth was observed under control (without amendments). The higher salinity under control resulted in shorter and fewer leaves due to osmotic stress which might have reduced the growth (Jacoby, 1994).

In the view recycling wastewater as irrigation source, the application of 25\% TTE with $75 \%$ DWW (1:3 ratio) is finest approach to make use of the wastewater for cultivation of cotton in efficient way with diminishing ecological contamination.

\section{Acknowledgements}

I thankful to M/s TALCO - DINTEC, Dindigul, Tamil Nadu, India, for the economic support and created flexible situation to conduct my research programme in meticulous manner.

\section{References}

Amer, K.H. 2010. Corn crop response under managing different irrigation and salinity levels. Agric. Water Mgt., 97: 1553-1563.

Ashley, D.A., B.D. Doss and O.L. Bennett. 1965. Relation of cotton leaf area index to plant growth and fruiting. Agron. J., 57: 61-64.
Indra, K. 2003. Studies on the effect of tannery effluent on soil and crop system. M.Sc., (Ag.) Thesis, Department of Environmental science, Tamil Nadu Agricultural University, Coimbatore, India.

Jacoby, B., 1994. Mechanisms involved in salt tolerance by plants. In: Proc. Pessarakli, M. (Ed.), Handbook of Plant and Crop Stress. Marcel Dekker, New York, Pp: 97-123.

Jagathjothi, N., K. Ramamoorthy and R. Kuttimani. 2011. Integrated nutrient management on growth and yield of rainfed direct sown finger millet. Res. on crops. 12 (1): 79-81.

Radford, D. J. 1967. Growth analysis formula, their use and abuse. Crop Sci., 7: 171-175.

Ritchey, K. D., C. M. Feldhake, R. B. Clark, and D. M. G. de Sousa. 1995. Improved water and nutrient uptake from subsurface layers of gypsum-amended soils. In: D.L. Karlen, R.J. Wright and W.O. Kemper (Eds.). Agricultural Utilization of Urban and Industrial By-Products. ASA Special Publication No.58, ASA, CSSA, and SSSA, Madison, Wis.

Sharma, D.C. and S.C. Mehrotra. 1993. Chromium toxicity effect on wheat (Triticum aestivum L. cv. HD 2204). Ind. J. Environ. Health. 35(4): 330-332.

Soyaslan, I. and R. Karaguzel. 2007. Investigation of water pollution in the Yalvac basin into egirdir lake, Turkey. Environ. Geol., 55: 1263-1268.

Tayyar, E., and N.A. Yapici. 2009. Seed germination characteristics of broad bean, lentil and common bean irrigated with different dilutions of pre-tanning effluents. INCI. 34(7): 514-517.

Watson, D. J. 1958. The dependence of net assimilation rate on leaf area index. Ann. Bot., 23: 37-54.

Williams, R. F. 1946. The physiology of plant growth with special reference to the concept of net assimilation rate. Ann. Bot., 10: 41-72.

\section{How to cite this article:}

Jagathjothi, N. and Mohamed Amanullah, M. 2018. Irrigation Management through Wastewater Recycling on Different Growth Indices of Cotton. Int.J.Curr.Microbiol.App.Sci. 7(09): 1377-1383. doi: https://doi.org/10.20546/ijcmas.2018.709.165 